\section{A substantial}

\section{- and expanding - business involvement with South Africa makes a world of sense}

\author{
Chris van Wyk
}

Senior General Manager,

Trust Bank of Africa Ltd,

P.O. Box 7694, Johannesburg 2000

Luncheon speech at the Belgian-South African Chamber of Commerce, 19 June 1979, Johannesburg

\section{The record speaks for itself}

South Africa offers foreign businessmen some of the most attractive rewards available anywhere in the world. It is very, very profitable to do business with South Africa: profit margins are generous, turnovers are high, costs low by international comparison, and bad debt or default - simply does not exist. On investments the yields have consistently been in the top league, if not the highest, in the developing world.

This situation contrasts vividly with the experience of international businessmen elsewhere in Africa, and in places in Latin-America and Asia. Belgian businessmen in particular have first-hand experience that business could be disastrous elsewhere in Africa!

South African exports are sought after, particularly those of agricultural and mining origin. For what other reason would South African exports to the USA have rocketed by $71 \%$ in 1978 (mainly Kruger Rands, diamonds and platinum) thereby pushing the USA into first place as export market? And why would exports to Switzerland have jumped by $113 \%$ and to Israel to $95 \%$ in the same year, if South African exporters do not excel in delivering the goods?

South Africans import with gusto. For many decades we have been keen buyers in foreign markets: of machinery, factory equipment, electrical machinery, transport equipment, electronic components and equipment, chemicals, toys, textiles - you name it. Despite substantial import replacement since the 1960 s, our import bill has been growing steadily and is likely to reach R10 billion this year. In addition to being enthusiastic buyers abroad, South Africans are also reliable payers, thereby enhancing our status as customers.

In regard to investment, Dr Joel Stern of Chase Manhattan Bank recently stated that returns on investment in South African ventures are 'among the best in the world'. Why else would foreigners by the end of 1977 have had invested a total of about R21,5 billion in South Africa? And could there be a different reason for Volkswagen Wolfsburg's recent decision to go ahead with investment of about R35 million in South Africa?
The amount of R220 million approved by the South African Reserve Bank for investment in South Africa through the financial rand, certainly testifies forcefully to the attractions of the Republic for international investors at this very moment.

Unfortunately, there is a constant tampering with the freedom of foreign businessmen to start, or proceed with, or indeed, to expand business with South Africa. And this meddling with non-residents' free choice to exploit the most profitable business opportunities particularly here must be irritating, and indeed, at times infuriating to international businessmen.

\section{The pressures are real but need not go unchallen- ged}

To many foreign businessmen 'maintaining a low visibility with respect to South Africa' has become the inphrase; many are ill at ease about their South African connection.

Now there is nothing that one can do about politics bedevilling business. The pressures are very real. Foreign businessmen cannot wish away the irritations pertaining to such things as the Sullivan Principles or the EEC Code of Conduct, or trade union intimidation or lobbying by the churches and universities against business with South Africa.

But politicians - be it the government of the day or the opposition - can equally not afford to ignore business opinion.

- It was pressure by American businessmen, who did not wish to sacrifice attractive business opportunities, that finally forced President Carter to establish diplomatic ties with Red China.

- It is to safeguard the interest of business and workers that the new British government publicly cautions against injudicious pressures that could harm the United Kingdom's trade with South Africa.

And you can think of many more examples of business opinion having a real impact on political decisions.

Foreign businessmen will know by now that there is a strong, logical and conclusive case to be argued in favour of their South African connection. I cannot believe that politically inspired pressure groups abroad who are mostly ill-informed, ill-advised and have questionable motives, can indefinitely defy the facts, the logic and the justification for foreign business association with South Africa.

At this very moment, while the world is being held at ransom by the oil producers, while prospects for world economic growth and international trade have become very bleak, exciting longer term business opportunities are evident in South Africa. In fact, the rather problematical international environment surrounding South Africa is acting as a generator of new projects, new ventures, and a multitude of innovations which will constitute numerous attractive business opportunities in the foreseeable future. Foreign businessmen must take note of these, and must assess for themselves how and to what extent they wish to participate. 
ominous in recent years. This has stimulated the drive towards greater self-sufficiency. Much time is being spent on devising a development strategy for agriculture, industry, services and mining - in fact, a total strategy that will bulwark our economic, social and military structures.

The thrust of industrial development following the desire for greater self-sufficiency is now being strengthened by the new and very serious dimension that the international oil situation has assumed. Bolder decisions with major business implications are being made every day. These evidently offer exciting opportunities for foreign trade with and investment in South Africa.

The South African economy and our lifestyle will certainly be adversely affected by the latest troublesome developments. In the short term, South Africa cannot escape the disruptive impact of the rapidly worsening international oil situation. But I daresay that to us the oil problem is relatively speaking more of a nuisance than a crisis, and is causing inconvenience rather than hardship; whereas in the rest of the world the threat of disruption, recession, sharply declining trade, growing unemployment and increasing currency instability seems much more ominous.

In these difficult circumstances I expect South Africa to remain a more attractive business partner and a brighter business prospect for the industrialized nations than most other countries.

\section{Why this optimistic note?}

\section{South Africa's abundant energy resources}

South Africa has all the energy substitutes for oil that hitherto have proven to be really viable.

Coal: This country's extensive coal resources combined with an advanced technology, present opportunities for more intensive exploitation, more exports, more efficient conversion into gas, electricity, steam, methanol and the numerous by-products required by the chemical industry. There is room for further technological innovation, more investment, more profitable export/import trade.

Moreover, the strategic significance of this huge coal reserve is quite staggering. It enables us to reduce our dependence on imported oil, it permits a major switchover to electricity and steam in transport, a substantially larger local production of liquid petroleum, it affords a pillar of strength to the balance of payments, it provides the basis for development of a thriving non-oil-based chemical industry. Most important, it assures the South African economy of an adequate energy base while many other countries may find their economies being constricted by an energy famine.

Uranium: Uranium remains an important alternative energy source. South Africa is richly endowed with uranium of good quality. We have both the mining technology and a well-developed application technology.

South Africa is prepared to share these technologies with, and to export uranium to, friendly countries. Uranium forms another pillar of our ability to become increasingly independent of imported oil as an energy source.

Sun energy: Meaningful technological advances are being made to develop this energy resource in South Africa.
Commercially viable breakthroughs are no longer a pipedream. We have plenty of sun. Sun energy utilization offers scope for another meaningful way of getting more independent from oil. Numerous new business opportunities will arise in the process of making the utilization of this energy resource commercially viable.

Suffice it to summarize at this juncture by emphasizing that with only a $25 \%$ dependence on imported oil as energy source, South Africa is excellently positioned to reduce its vulnerability to the international oil crisis without serious disruption of the availability of energy to industry, trade, transport and indeed, the whole economy. Moreover, as the international crude oil problem threatens to destroy balance of payments equilibrium in most countries, South Africa has viable alternatives to offer for export to an energy-hungry world; the very same alternatives that will increasingly help us to displace imports of oil. South Africa has an outstanding ability to cushion the devastating impact that the international oil famine and spiralling oil prices will have on most economies.

\section{Balance of payments resilience}

In addition to having energy available for export and to substitute for oil imports, South Africa is in the unique position of possessing in abundance all the hedging commodities that are so much sought after when panic grips the world's markets and financial centres.

Unquestionably, it is widely anticipated that the latest adverse turn in the industrial world's oil situation will have a shattering impact on the world economy. Growing currency instability is expected, rising inflation, declining growth, rising unemployment and more social and political instability. In such a world the oil barons themselves as well as other holders of money assets seek almost frantically for the most reliable physical stores of wealth.

Hence the surging interest in gold bullion, gold coins, diamonds, platinum and other hedging commodities that we are witnessing again.

South Africa possesses these hedging commodities in abundance. The sustained world demand for these provide fundamental strength to our balance of payments. The more of this strength we have, the less likely it becomes that our authorities will have to interfere drastically with trade and financial flows to protect the balance of payments. Elsewhere in the world a substantially greater protectionist action may occur in order to protect rapidly worsening trade balances. Moreover, the real purchasing power available for non-oil imports is likely to be drastically reduced in most countries.

Thus, while South Africa will certainly also have to use its available foreign exchange sparingly, it seems that despite the sharp rise in the oil bill, South Africa will, relatively speaking, be one of only a small number of countries that will in the foreseeable future, be able to afford a fairly high level of imports from the major exporting countries.

Equally important is the fact that South Africa will continue to be able to uphold its impeccable record of non-default on its international obligations. 
source of energy in this country.

Households will do away with oil heaters. Numerous households will consider the electric car as a second car as soon as it becomes a practical proposition.

The South African Railways intends spending around R450 million on electrification and steam locomotion over the next three years or so. The suppliers of rolling stock, electrical traction units, carriages and servicing equipment to the South African Railways should therefore expect a surge in new contracts. Similarly ESCOM suppliers must expect continued buoyancy in demand.

Other public transportation systems, such as urban and suburban bus transport, will be expanded. The dust will be brushed off the plans for an underground rail system for Johannesburg. Some people feel that a return to the old city tram system should be considered. And so one can go on expounding the new challenges.

Industry will increasingly move away from oil furnaces, oil burners and the like to electricity and steam, which in the final analysis means an increased reliance on coal-based energy.

All these developments spell out countless opportunities for trade, investment, and exchange of knowhow and technology. South African suppliers (which in a number of cases have foreign shareholders) as well as offshore companies should certainly expect trading and manufacturing opportunities aplenty in the years to come. And hand in hand with these will go investment and expansion opportunities at attractive yields.

\section{Sophisticated engineering projects}

The announcement of the Atlantis Diesel Engine Project, in which foreign companies play a major role as technical partners, highlights another facet of the more recent trend of industrial development in South Africa. Ancillary developments are the establishment of a foundry, the local manufacture of diesel injection systems and vast expansion of the local vehicle component industry. Still another adjunct of these developments is the local manufacture of gearboxes, rear-axles and related drive systems on a partnership basis with foreigners.

These projects of necessity imply substantial orders for imported machine tools, components, technology and know-how. They could lead to future exports. They present new investment opportunities.

\section{Expansions in the chemical industry}

The erection of ethanol plants has become a viable proposition in South Africa. The vast and sophisticated COALPLEX venture demonstrates in no uncertain manner our capability to produce the widest conceivable range of substitute coal by-products for the burgeoning chemical industry.

South Africa has a well-developed technology for the production of methanol - we have been producing it for years. At comparatively short notice the production of this additive to petrol could be greatly expanded.

Again, these represent numerous opportunities for a substantial foreign business involvement in South Africa.

I trust that by highlighting a number of the already-inprocess and emerging ventures and opportunities in South Africa, I have managed to support my opening thesis that it makes sense, and is likely to make even more sense in future, for foreign businessmen to maintain and strengthen their business ties with South Africa.

For those who have a specific interest in investment here, I submit a few facts which they may wish to ponder.

\section{South African Investments are among the best}

A recent study has shown that conglomerates achieve an average $14,9 \%$ (after tax) return on invested capital in South Africa compared with $9,5 \%$ in the USA. Singleproduct businesses return $14,3 \%$ here compared with $10,8 \%$ in the USA.

Average pre-tax returns on shareholders' funds in a number of major South African sectors over the three years $1976-1978$ are shown in Table 1.

Table 1 Average pre-tax returns on shareholders' funds, three years to mid-1978*

\begin{tabular}{ll}
\hline \multicolumn{1}{c}{ Sector } & $\%$ \\
\hline Food & 24,7 \\
Clothing & 36,7 \\
Paper & 22,5 \\
Packaging & 31,3 \\
Chemicals & 26,7 \\
Non-metalic minerals & 42,5 \\
Base metals & 44,3 \\
Industrial machinery, engineering and & \\
electronics & 22,5 \\
Overall average & 31,4 \\
\hline
\end{tabular}

*The average after tax return is approximately $18,5 \%$.

(Note: reduce pre-tax returns by roughly $40 \%$ to estimate after tax returns.)

London stockbrokers, Jampes Capel and Co., have produced the following comparative returns on shareholders' equity for selected mining companies.

Table 2 Percentage return on shareholders' equity

\begin{tabular}{lcc}
\hline \multicolumn{1}{c}{ Country } & $\begin{array}{c}\text { Over 5 years } \\
1971-1975\end{array}$ & $\begin{array}{c}\text { Over 10 years } \\
1966-1975\end{array}$ \\
\hline USA & $14,0 \%$ & $12,5 \%$ \\
Australia & $12,5 \%$ & $10,6 \%$ \\
South Africa* & $18,3 \%$ & $15,1 \%$
\end{tabular}

*South Africa's comparative advantage in mining investment returns has no doubt improved since 1975.

\section{Closing remarks}

In conclusion a resumé of other important considerations pertaining to a business relationship with South Africa may not be out of place.

- In South Africa a growing emphasis is being placed by government on promoting the free enterprise system.

- The acceptance by the government of most of the recommendations of the Wiehahn and Riekert Commissions is a quantum jump in the process of black advancement. It must now, more than ever before, be abundantly clear that South Africans are purposefully working towards equal opportunities for all races. 
- The convenient location of South Africa in relation to other African nations places this country in a strategic position to capture major export opportunities.

- The South African infra-structure is highly developed and geared to accommodate another sustained upswing of the nature of that which occurred during the golden sixties.

- South Africa has vast human resources to be trained and employed productively; hence to constitute a major failure addition both to the skilled labour corps and to consumer purchasing power.

- More jobs, better education and training, and higher average standards of living are the keys to the peaceful advancement of all the people of this"country. These are the pre-requisites for sustained social development, political maturity and participation in government, particularly of our society's 'have nots'. But for this to happen, we need a sustained expansion of our economy. And for that to happen, South Africa must develop its international trade and financial connections to the fullest possible extent. So let us not be bluffed into believing that South Africa's foreign relationships must be broken to achieve black advancement. That is nonsense. Just the opposite is required.
The beauty of it all is that the Western world can best serve its 'human rights' and 'social justice' causes with respect to South Africa by merely showing good business sense. So, there is a stiff challenge for all international businessmen to see that good business sense prevails over what is mostly utter political nonsense.

- I believe it needs emphasizing that the major industrial countries need not fear the humiliations here that they so often suffer in other parts of the world. Our country does not nationalize foreign investments. We do not renege on trade agreements. We respect the sanctity of contracts. We welcome foreign technicians and knowhow, we do not drive them out of our country. To underscore this point, I need only remind you of the bizarre spectacle provided by the stampede of major international companies and their staff out of Iran, of the blatant expropriation of property and the shameless breach of contracts there.

There is no question that it makes good sense for foreign businessmen to continue doing profitable business with South Africa. Of course, the benefits are mutual, and the opportunities are numerous with a high reward potential despite the storm clouds gathering on the international economic horizon. You should stay involved, profitably. 